\title{
Communication
}

\section{Optimization of Alkaline Flocculation for Harvesting of Scenedesmus quadricauda \#507 and Chaetoceros muelleri \#862}

\section{Shuhao Huo ${ }^{1,3}$, Zhongming Wang ${ }^{2}$, Shunni Zhu ${ }^{2}$, Fengjie Cui ${ }^{1}$, Bin Zou ${ }^{1}$, Wenhua You ${ }^{4}$, Zhenhong Yuan ${ }^{2, *}$ and Renjie Dong ${ }^{3, *}$}

1 School of Food and Biological Engineering, Jiangsu University, Zhenjiang 212013, Jiangsu, China; E-Mails: huoshuhao@yeah.net (S.H.); fengjiecui@163.com (F.C.); binzou2009@163.com (B.Z.)

2 Guangzhou Institute of Energy Conversion, Chinese Academy of Sciences, Guangzhou 510640, Guangdong, China; E-Mails: wangzm@ms.giec.ac.cn (Z.W.); zhusn@ms.giec.ac.cn (S.Z.)

3 College of Engineering, China Agricultural University, Beijing 100083, China

4 School of the Environment and Safety Engineering, Jiangsu University, Zhenjiang 212013, Jiangsu, China; E-Mail: wenhuayou186@gmail.com

* Authors to whom correspondence should be addressed;

E-Mails: yuanzh@ms.giec.ac.cn (Z.Y.); rjdong@cau.edu.net (R.D.);

Tel.: +86-20-8705-7760 (Z.Y.); Fax: +86-20-8705-7737 (Z.Y.);

Tel./Fax: +86-10-6273-7885 (R.D.).

Received: 11 June 2014; in revised form: 13 August 2014 / Accepted: 17 September 2014 /

Published: 24 September 2014

\begin{abstract}
A response surface methodology (RSM) was used to evaluate the effects of $\mathrm{pH}$ and microalgal biomass concentration (BC) on alkaline flocculating activity for harvesting one freshwater green algae Scenedesmus quadricauda \#507 and one marine diatom Chaetoceros muelleri \#862. The $\mathrm{pH}$ value and $\mathrm{BC}$ were in range of 9.0-12.0 and $0.20-2.30 \mathrm{~g} / \mathrm{L}$, respectively. Very high regression coefficient between the variables and the response indicates excellent evaluation of experimental data by second-order regressions. Optimum conditions for flocculating activity were estimated as follows: (i) $\mathrm{pH} 11.6$, $\mathrm{BC} 0.54 \mathrm{~g} / \mathrm{L}$ for strain \#507 and (ii) $\mathrm{pH} 11.5$, BC $0.42 \mathrm{~g} / \mathrm{L}$ for strain \#862. The maximum flocculating activity was around $94.7 \%$ and $100 \%$, respectively. Furthermore, the addition of synthetic ocean water (SOW) to the freshwater \#507 culture can increase the flocculating activity from $82.13 \%-88.79 \%$ in low algae concentration $(0.52 \mathrm{~g} / \mathrm{L})$ and $82.92 \%-95.60 \%$ in high concentration $(2.66 \mathrm{~g} / \mathrm{L})$.
\end{abstract}


Keywords: microalgae harvesting; flocculation; alkaline; response surface methodology; synthetic ocean water

\section{Introduction}

Microalgae cultivation for biofuel production have been considered as an important contributor to Greenhouse Gases mitigation and energy security due to its fast growth rates, voracious appetite for $\mathrm{CO}_{2}$, wide adaptability, and high energy source content [1,2]. The two most important classes of microalgae in terms of abundance and lipid content are the green algae (Chlorophyceae) and diatoms (Bacillariophyceae) [3]. Lipid can be refined into biodiesel for land transportation and even for aviation use.

The concentration of microalgae achieved in the industrial application is usually between 0.3 and $0.5 \mathrm{~g}$ dry cell/L or $5.0 \mathrm{~g}$ dry cell/L at best $[1,4]$. Moreover, microalgae are small with a diameter of 1-30 $\mu \mathrm{m}$. As a result, harvesting microalgae from their medium is difficult and expensive [5]. Flocculation is considered to be an effective and convenient bulk harvesting process, which reduces/neutralizes the negative surface charge of microalgal cells, allowing them to aggregate into larger lumps with an efficiency of $>80 \%$ [1]. A large number of flocculants including toxic chemical such as aluminum, iron salts [6] and polyelectrolyte [3] as well as expensive biofloculants like chitosan [7] have been used.

Algae and cyanobacteria could be flocculated by high $\mathrm{pH}$ values [8,9]. Floc particles usually begin to form well above $\mathrm{pH} 10$ and only complete at $\mathrm{pH} 11$ [10]. Alkaline flocculation could be an attractive alternative because it is low-cost, low energy consumption, non-toxic to microalgal cells and the high pH effectively sterilizes the microalgal biomass as well as the process water. Previous studies have investigated the interactive effects of $\mathrm{pH}, \mathrm{Mg}^{2+}, \mathrm{Ca}^{2+}$, concentration and microalgal biomass concentration on flocculation of Chlorella. The flocculation activity is highly variable and is influenced mainly by the amount of magnesium hydroxide [8,11-15]. This method was studied to a number of microalgal strains (such as Chlorella vulgaris [11-13], Scenedesmus sp. [13], Chlorococcum sp. [13], Dunaliella salina [14]). Besson and Guiraud have found the flow rate of $\mathrm{NaOH}$ addition had no effect on the Dunaliella salina recovery efficiency and non-harvested cells remained viable during $\mathrm{pH}$ increase which could be used as inoculum for a new culture [8].

During the practical production, the values of $\mathrm{pH}$ and biomass concentration (BC) are not fixed, so it not appropriate to use the one factor experimental design. As we know, few researches investigated the interacting effects of the key factors: $\mathrm{pH}$ value and $\mathrm{BC}$ to date. In this study, response surface methodology (RSM) was used to evaluate the effects of the two factors of alkaline flocculation of one freshwater green algae Scenedesmus quadricauda \#507 and one marine diatom Chaetoceros muelleri \#862. Furthermore, the addition of synthetic ocean water (SOW) to the medium for flocculating activity improvement was also investigated. 


\section{Materials and Methods}

\subsection{Microalgal Strain and Culture Conditions}

Freshwater green algae Scenedesmus quadricauda \#507 and marine diatom Chaetoceros muelleri \#862 were obtained from Freshwater Algae Culture Collection (Wuhan, Hubei, China). For the cultivation of two strains, BG11 medium [16] and f/2 medium [17] were used respectively. About $100 \mathrm{~mL}$ pre-culture broths mentioned above were inoculated into a vertical tubular photobioreactor containing 1.0 L medium. The vertical tubular photobioreactor consisted of glass tubes of $70.0 \mathrm{~cm}$ heights and $5.0 \mathrm{~cm}$ outside diameters. Light was supplied by cool white fluorescent lamps at the single side of the photobioreactor (light intensity: $200 \pm 50 \mu \mathrm{E} /\left(\mathrm{m}^{2} \mathrm{~s}\right)$ ). Aeration and mixing were achieved by the sparging air enriched with $6.0 \% \mathrm{CO}_{2}$ through a glass-filter, which was inserted to the bottom of the reactor and the flow rate of gas was $0.5 \mathrm{vvm}$ regulated by the gas flow meter (Model G, Aalborg Instruments \& Controls, Inc., Orange-burg, NY, USA). The temperature of the culture media was $25 \pm 1{ }^{\circ} \mathrm{C}$ regulated by the room air conditioner (Gree Electric Appliances Inc., Zhuhai, Guangdong, China). After 6 days of cultivation, the cultures were used for flocculation experiment.

\subsection{Determination of Flocculating Activity}

After the flocculation of microalgal cells; an aliquot of culture was withdrawn and used to measure OD 680 (optical density at the wavelength of $680 \mathrm{~nm}$ ). The flocculation activity was calculated according to the following equation:

$$
\text { Flocculating activity }(\%)=(1-A / B) \times 100
$$

where, $A$ is the optical density of the sample at $680 \mathrm{~nm}$ and $B$ is the optical density of the algal culture before the flocculation measured at $680 \mathrm{~nm}$.

\subsection{Alkaline Flocculation}

Similar to $\mathrm{Wu}$ et al.'s method [8], flocculation experiments were run with small volumes of medium $(25 \mathrm{~mL})$ distributed in cylindrical glass tubes $(50 \mathrm{~mL})$. Effective flocculation was achieved simply by adjusting the $\mathrm{pH}$ accurately between 9.0 and 12.0 with $1.0 \mathrm{~N} \mathrm{NaOH}$ or $1.0 \mathrm{~N} \mathrm{HCl}$. pH was measured by a portable $\mathrm{pH}$ analyzer (Yilun, $\mathrm{pH}-3 \mathrm{C}$, Shanghai, China). After the $\mathrm{pH}$ had been adjusted, the glass tube was shaken thoroughly about $10 \mathrm{~s}$ and allowed to stand at room temperature for $30 \mathrm{~min}$. Then, an aliquot of medium was withdrawn and used to measure OD680.

\subsection{Starving the Cultures of $\mathrm{CO}_{2}$ Prior to Harvest}

"Starving" procedure as follows: the $\mathrm{pH}$ of the photosynthesizing algae to rise by allowing the cells to remove excess $\mathrm{CO}_{2}$ from the medium for $180 \mathrm{~min}$ prior to harvest by bubbling air through the medium.

\subsection{Effect of Synthetic Ocean Water on Flocculating Activity}

For the later experiment, SOW was added to the medium of freshwater green algae prior to $\mathrm{pH}$ adjustment. Composition of SOW: $\mathrm{NaCl} 24.540$ g/L, $\mathrm{Na}_{2} \mathrm{SO}_{4} 4.090$ g/L, KCl 0.700 g/L, 
$\mathrm{NaHCO}_{3} 0.200 \mathrm{~g} / \mathrm{L}, \mathrm{KBr} 0.100 \mathrm{~g} / \mathrm{L}, \mathrm{H}_{3} \mathrm{BO}_{3} 0.003 \mathrm{~g} / \mathrm{L}, \mathrm{NaF} 0.003 \mathrm{~g} / \mathrm{L}, \mathrm{MgCl}_{2} \cdot 6 \mathrm{H}_{2} \mathrm{O} 11.100 \mathrm{~g} / \mathrm{L}$, $\mathrm{CaCl}_{2} \cdot 2 \mathrm{H}_{2} \mathrm{O} 1.540 \mathrm{~g} / \mathrm{L}, \mathrm{SrCl}_{2} \cdot 6 \mathrm{H}_{2} \mathrm{O} 0.017 \mathrm{~g} / \mathrm{L}$. Final salinity is $35 \mathrm{psu}$. The final dilution factors of SOW were 0.001, 0.002, 0.004 and 0.006 (Dilution factors = SOW additive amount/Total amount).

\subsection{Experimental Design and Statistical Analysis}

A central composite design (CCD) was used for the experiments to investigate the effects of $\mathrm{pH}$ value and $\mathrm{BC}$ on the flocculating activity. Five level-2 factor experimental blocks were constructed using the Design-export 8.0 software (Stat-Ease, Minneapolis, MN, USA), and the quality of analysis model evaluated based on an analysis of variance (ANOVA). The response variable $(Y)$ that representing the flocculating activity was fitted using a second-order model in the form of a quadratic polynomial equation:

$$
Y=\beta_{0}+\sum_{i=1}^{m} \beta_{1} x_{i}+\sum_{i<j}^{m} \beta_{i j} x_{i} x_{j}+\sum_{i=1}^{m} \beta_{i i} x_{i}^{2}
$$

where, $Y$ is the response variable to be modeled, $x_{i}$ and $x_{j}$ are independent variables representing the $\mathrm{pH}$ and $\mathrm{BC}, \beta_{0}, \beta_{i}$, and $\beta_{i i}$ are the offset term, linear coefficient, and quadratic coefficient, respectively, and $\beta_{i j}$ is the term that reflects the interaction between $x_{i}$ and $x_{j}[18]$.

\section{Results and Discussion}

\subsection{Starving the Cultures of $\mathrm{CO}_{2}$ Prior to Harvest}

The amount of flocculant needed to flocculate can affect the operating cost of algae harvesting systems. Natural increase of culture $\mathrm{pH}$ by photosynthesis could reduce the amount of base consumed [14]. As Figure 1 shows, because of the photosynthesizing, $\mathrm{pH}$ of algae cultures rose from $\mathrm{pH} 6.1$ to 8.5 (Chaetoceros muelleri \#862) and from pH 6.6 to 9.0 (Scenedesmus quadricauda \#507) by allowing the cells to remove excess $\mathrm{CO}_{2}$ from the medium for $3 \mathrm{~h}$ prior to harvest by bubbling air through the medium. By starving the cultures of $\mathrm{CO}_{2}$ just prior to harvest, it is possible to reduce $\mathrm{NaOH}$ additive amount. Schlesinger et al. [10] reported this operation would halve the amount of $\mathrm{Ca}(\mathrm{OH})_{2}$ needed to induce flocculation when used $\mathrm{Ca}(\mathrm{OH})_{2}$ as a type of alkaline flocculant.

Figure 1. The change of $\mathrm{pH}$ values after starving the cultures of $\mathrm{CO}_{2}$ (\#507: Scenedesmus quadricauda \#507 and \#862: Chaetoceros muelleri \#862).

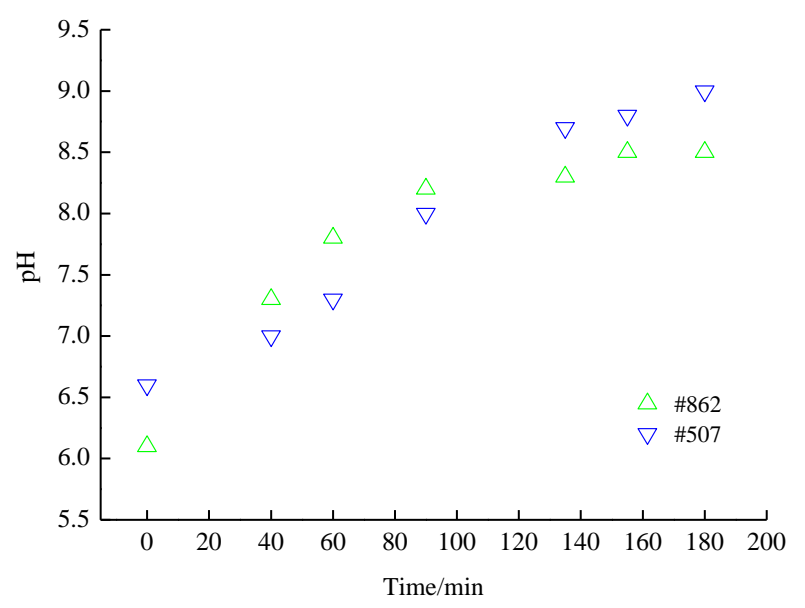




\subsection{Optimization of Alkaline Flocculation}

In the present study, a three-dimensional plot of the response surfaces showed the interacting effects of the key factors, $\mathrm{pH}$ value and $\mathrm{BC}$ on flocculating activity (Figure 2). For the strain \#507, the maximum flocculating activity was $94.7 \%$, corresponding to $\mathrm{pH}$ value and $\mathrm{BC}$ of 11.6 and $0.54 \mathrm{~g} / \mathrm{L}$, respectively. For the strain \#862, the maximum flocculating activity was $100 \%$, corresponding to $\mathrm{pH}$ value and $\mathrm{BC}$ of 11.5 and $0.42 \mathrm{~g} / \mathrm{L}$, respectively.

Figure 2. Response surface plot representing effect of $\mathrm{pH}$ and biomass concentration on flocculating activity (a) Scenedesmus quadricauda \#507; (b) Chaetoceros muelleri \#862).

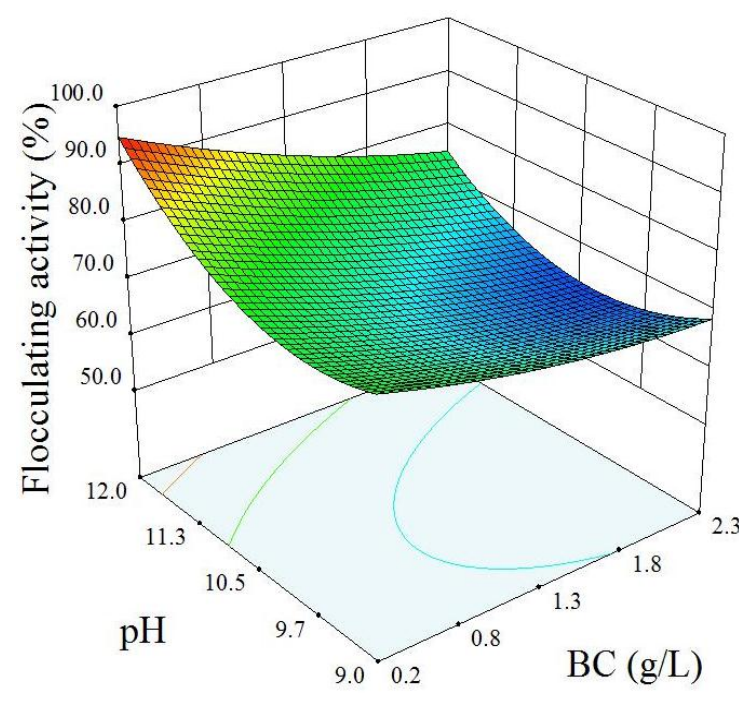

(a)

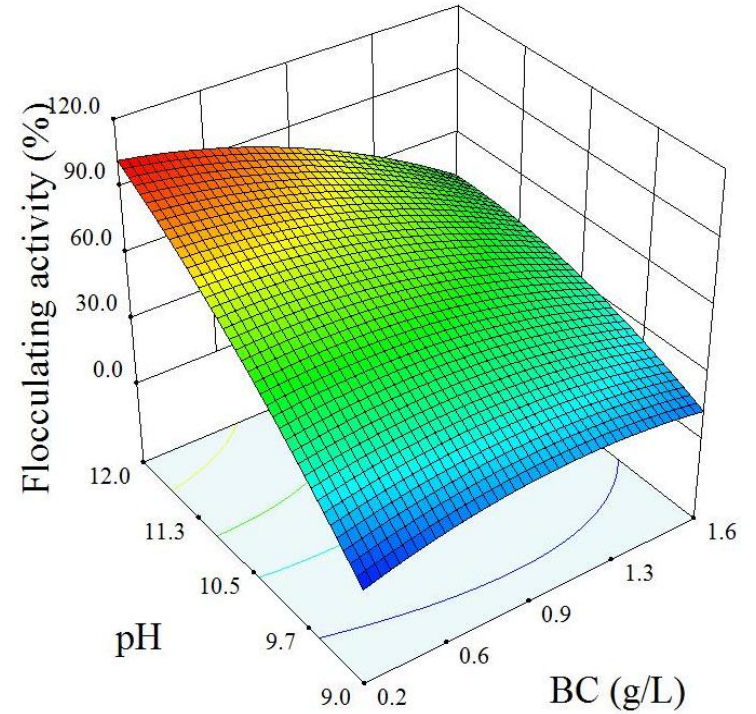

(b)

The ANOVA for the second-order regression equation (Table 1) showed that the $F$-values of the two models were 104.87 and 73.46, respectively, which implied the two models were both significant. Regression analysis of the experimental design demonstrated that the linear model terms $(\mathrm{BC}, \mathrm{pH})$, quadratic model terms $\left(\mathrm{BC}^{2}, \mathrm{pH}^{2}\right)$ and interactive model terms $(\mathrm{BC} \times \mathrm{pH})$ were all highly significant $(p<0.05)$. Table 2 presents the estimated regression coefficients for all factors and their respective values with regards to the flocculating activity. As shown in Table 2, compared to the coefficient estimate, it clearly appears that the significance follows: $\mathrm{pH}^{2}>\mathrm{BC}>\mathrm{pH}>\mathrm{BC} \times \mathrm{pH}>\mathrm{BC}^{2}$ for Scenedesmus quadricauda \#507 and $\mathrm{pH}>\mathrm{BC} \times \mathrm{pH}>\mathrm{BC}>\mathrm{BC}^{2}>\mathrm{pH}^{2}$ for Chaetoceros muelleri \#862. The positive and negative coefficients for the linear terms suggested the improved flocculating activity can be achieved by increasing $\mathrm{pH}$ value or decreasing BC. The final equations in terms of the actual factors are shown in Table 3. The pred- $R^{2}$ of 0.915 and 0.912 were in reasonable agreement with the adj- $R^{2}$. The proposed model equations provide satisfactory and accurate results. 
Table 1. Analysis of Variance (ANOVA) for Response Surface Quadratic Model.

\begin{tabular}{|c|c|c|c|c|c|}
\hline Source & Sum of Squares & $\mathrm{DF}^{\mathbf{a}}$ & Mean Square & $F$-Value & $p$-value \\
\hline \multicolumn{6}{|c|}{ Scenedesmus quadricauda \#507 } \\
\hline Model & $1,207.78$ & 5 & 241.56 & 104.87 & $<0.0001$ \\
\hline $\mathrm{BC}$ & 414.70 & 1 & 414.70 & 180.04 & $<0.0001$ \\
\hline $\mathrm{pH}$ & 268.41 & 1 & 268.41 & 116.53 & $<0.0001$ \\
\hline $\mathrm{BC} \times \mathrm{pH}$ & 26.11 & 1 & 26.11 & 11.34 & 0.0120 \\
\hline $\mathrm{BC}^{2}$ & 26.38 & 1 & 26.38 & 11.45 & 0.0117 \\
\hline $\mathrm{pH}^{2}$ & 493.46 & 1 & 493.46 & 214.23 & $<0.0001$ \\
\hline Residual & 16.12 & 7 & 2.30 & - & - \\
\hline Lack of Fit & 14.24 & 3 & 4.75 & 10.10 & 0.0245 \\
\hline Pure Error & 1.88 & 4 & 0.47 & - & - \\
\hline Cor Total & $1,223.90$ & 12 & - & - & - \\
\hline \multicolumn{6}{|c|}{ Chaetoceros muelleri \#862 } \\
\hline Model & $11,517.07$ & 5 & $2,303.41$ & 73.46 & $<0.0001$ \\
\hline $\mathrm{BC}$ & $1,423.51$ & 1 & $1,423.51$ & 45.40 & 0.0003 \\
\hline $\mathrm{pH}$ & $7,940.07$ & 1 & $7,940.07$ & 253.23 & $<0.0001$ \\
\hline $\mathrm{BC} \times \mathrm{pH}$ & $1,216.27$ & 1 & $1,216.27$ & 38.79 & 0.0004 \\
\hline $\mathrm{BC}^{2}$ & 600.57 & 1 & 600.57 & 19.15 & 0.0032 \\
\hline $\mathrm{pH}^{2}$ & 457.43 & 1 & 457.43 & 14.59 & 0.0065 \\
\hline Residual & 219.48 & 7 & 31.35 & - & - \\
\hline Lack of Fit & 125.43 & 3 & 41.81 & 1.78 & 0.2903 \\
\hline Pure Error & 94.05 & 4 & 23.51 & - & - \\
\hline Cor Total & $11,736.55$ & 12 & - & - & - \\
\hline
\end{tabular}

${ }^{a}$ DF: degree of freedom.

Table 2. Estimated regression coefficients for flocculating activity.

\begin{tabular}{|c|c|c|c|c|c|c|}
\hline Factor & Coefficient Estimate & DF $^{\text {a }}$ & Standard Error & $95 \% \mathrm{CI}^{\mathrm{b}}$ Low & 95\% CI High & VIF $^{c}$ \\
\hline \multicolumn{7}{|c|}{ Scenedesmus quadricauda \#507 } \\
\hline Intercept & 68.94 & 1 & 0.68 & 67.33 & 70.54 & - \\
\hline $\mathrm{BC}$ & -7.20 & 1 & 0.54 & -8.47 & -5.93 & 1.00 \\
\hline $\mathrm{pH}$ & 5.79 & 1 & 0.54 & 4.52 & 7.06 & 1.00 \\
\hline $\mathrm{BC} \times \mathrm{pH}$ & -2.56 & 1 & 0.76 & -4.35 & -0.76 & 1.00 \\
\hline $\mathrm{BC}^{2}$ & 1.95 & 1 & 0.58 & 0.59 & 3.31 & 1.02 \\
\hline $\mathrm{pH}^{2}$ & 8.42 & 1 & 0.58 & 7.06 & 9.78 & 1.02 \\
\hline \multicolumn{7}{|c|}{ Chaetoceros muelleri \#862 } \\
\hline Intercept & 57.50 & 1 & 2.50 & 51.58 & 63.42 & - \\
\hline $\mathrm{BC}$ & -13.34 & 1 & 1.98 & -18.02 & -8.66 & 1.00 \\
\hline $\mathrm{pH}$ & 31.50 & 1 & 1.98 & 26.82 & 36.19 & 1.00 \\
\hline $\mathrm{BC} \times \mathrm{pH}$ & -17.44 & 1 & 2.80 & -24.06 & -10.82 & 1.00 \\
\hline $\mathrm{BC}^{2}$ & -9.29 & 1 & 2.12 & -14.31 & -4.27 & 1.02 \\
\hline $\mathrm{pH}^{2}$ & -8.11 & 1 & 2.12 & -13.13 & -3.09 & 1.02 \\
\hline
\end{tabular}

${ }^{\mathrm{a}} \mathrm{DF}$ : degree of freedom. ${ }^{\mathrm{b}} \mathrm{CI}$ : confidence interval. ${ }^{\mathrm{c}}$ VIF: variance inflation factor. 
Table 3. The final equation in terms of the actual factors.

\begin{tabular}{|c|c|c|c|c|}
\hline Strains & Equations & $R^{2}$ & $\overline{A d j}-R^{2}$ & Pred- $R^{2}$ \\
\hline$\# 507^{\mathrm{a}}$ & $\begin{array}{c}\mathrm{Y}=+811.5+15.5 \times \mathrm{BC}-147.6 \times \mathrm{pH}-3.3 \times \mathrm{BC} \times \\
\mathrm{pH}+3.6 \times \mathrm{BC}^{2}+7.5 \times \mathrm{pH}^{2}\end{array}$ & 0.987 & 0.977 & 0.915 \\
\hline$\# 862^{\mathrm{b}}$ & $\begin{array}{c}\mathrm{Y}=-1351.3+370.6 \times \mathrm{BC}+209.4 \times \mathrm{pH}-31.8 \times \mathrm{BC} \times \\
\mathrm{pH}-34.9 \times \mathrm{BC}^{2}-7.2 \times \mathrm{pH}^{2}\end{array}$ & 0.981 & 0.968 & 0.912 \\
\hline
\end{tabular}

${ }^{\mathrm{a}}$ Scenedesmus quadricauda \#507; ${ }^{\mathrm{b}}$ Chaetoceros muelleri \#862.

\subsection{Microscopic Observation of Algal Cells with Increasing pH}

As Figure 3 shows, for the strain \#507, with the increasing $\mathrm{pH}$ values, the cells still existed integrally as normal cells, with seta disappearance vaguely. No clearly sediment produced. To the contrary, for strain \#862, as the $\mathrm{pH}$ was increased to 10.7, substantial sediment occurred. By $\mathrm{pH} 11.8$, bulk precipitation was significantly generated, the dense algal cells were wrapped in it. Blanchemain et al. [19] noted that cell lysis occurred after $1 \mathrm{~h}$. We did not observe apparent deterioration of microalgal biomass harvested even using $\mathrm{pH} 11.5$ after $6 \mathrm{~h}$ flocculation.

As we know, there has a high concentration $\mathrm{Mg}^{2+}, \mathrm{Ca}^{2+}$ in the sea water which was precipitated when the $\mathrm{pH}$ value became alkaline. The flocculation is induced by precipitation of $\mathrm{Mg}(\mathrm{OH})_{2}$ at $\mathrm{pH}$ values between 9.5 and $11.5, \mathrm{CaCO}_{3}$ at $\mathrm{pH}$ value $>9.5$ [20]. Wu et al. [8] explained that $\mathrm{Mg}(\mathrm{OH})_{2}$ precipitate coagulated microalgal cells by sweeping flocculation and charge neutralization. However, Schlesinger et al. [10] found flocculation is not related to co-precipitation with iron, magnesium, phosphate or $\mathrm{Ca}(\mathrm{OH})_{2}$. Flocculation is still probably related to cell characteristics.

Figure 3. Morphotogical changes of algal cells with increasing $\mathrm{pH}$ observed with polarizing microscope at $\times 400$ magnification after $6 \mathrm{~h}$ flocculation (a) Scenedesmus quadricauda \#507;

(b) Chaetoceros muelleri \#862.
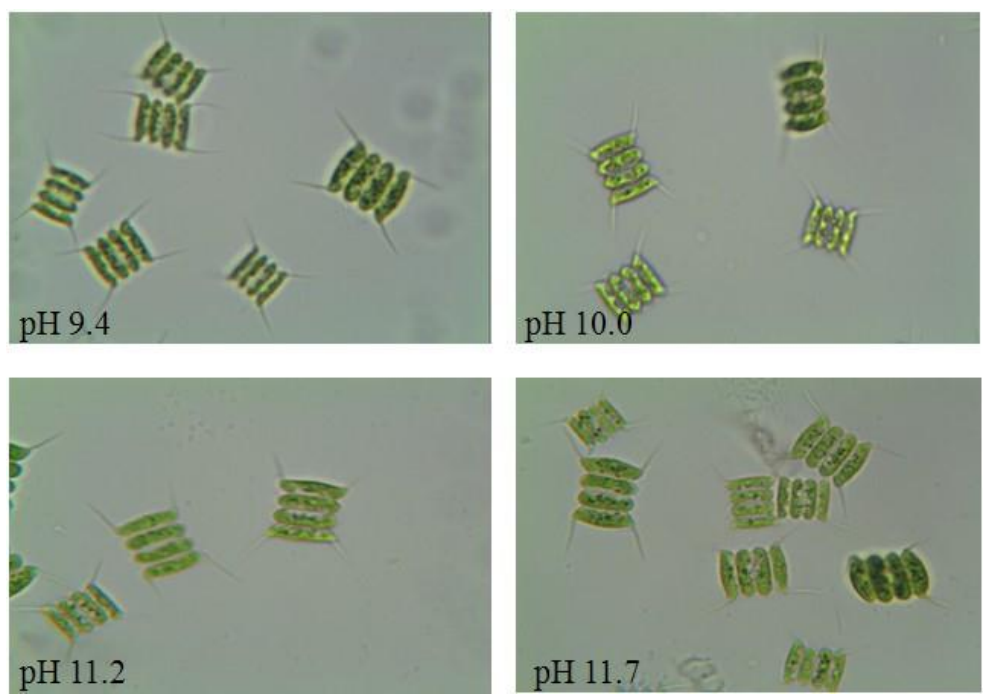

(a) 
Figure 3. Cont.
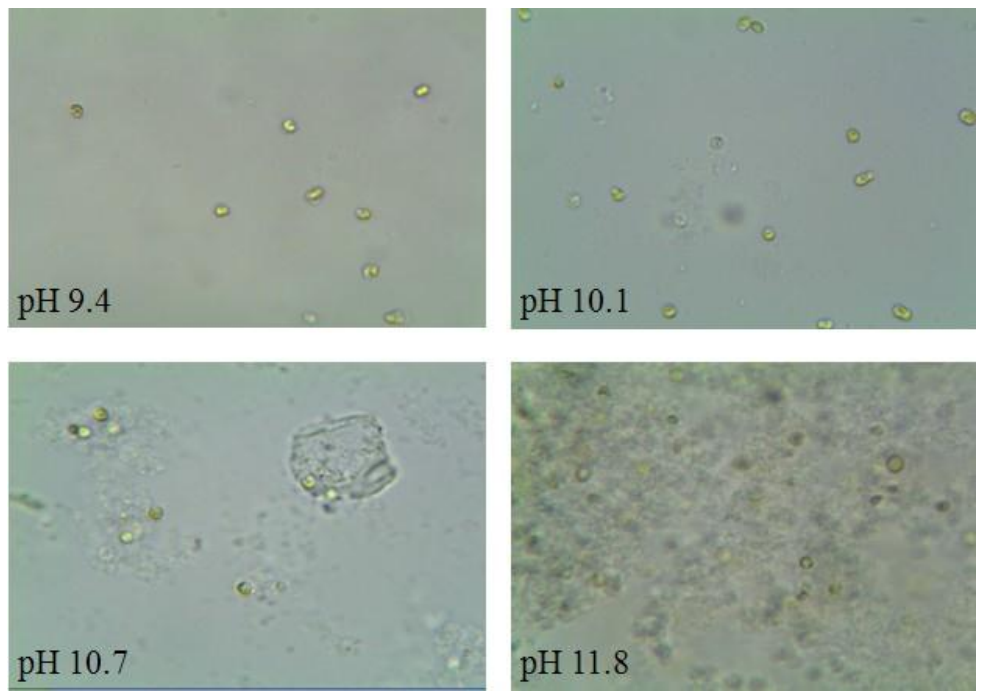

(b)

\subsection{Improvement of Flocculating Activity with the Addition of Synthetic Ocean Water}

As Figure 4 shows, a cheap additive, SOW, was added to the freshwater Scenedesmus quadricauda \#507 culture can improve flocculating activity obviously. The flocculating activity can be increased from $82.13 \%-88.79 \%$ in low algal concentration $(0.52 \mathrm{~g} / \mathrm{L})$, and $82.92 \%-95.60 \%$ in high algal concentration $(2.66 \mathrm{~g} / \mathrm{L})$. In low algal concentration condition, a small quantity of SOW (dilution factor is 0.002 ) is needed to close to the max flocculating activity, while a large quantity of SOW (dilution factor is 0.006 ) is needed to close to the max flocculating activity in the high concentration condition. The two microalgae concentrations' ratio is about 5, but the quantity ratio of SOW needed is 3 . The result means the denser the cell suspension, the less flocculant needed per cell. No direct linear relationship between number of cells to be flocculated and the amount of flocculant required. It was similar with Schlesinger et al.'s [10] result whereby they found the amount of flocculant required is directly related to the logarithm of cell density.

Figure 4. Improvement of flocculating activity of Scenedesmus quadricauda \#507 by synthetic ocean water added (pH 11.5, 10 min stand of the concentration $0.52 \mathrm{~g} / \mathrm{L}$ ).

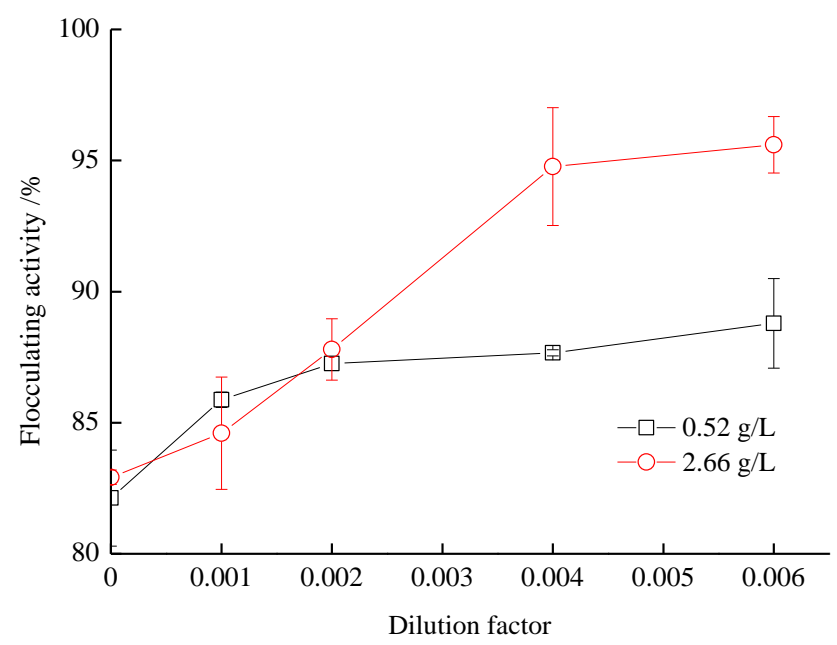




\section{Conclusions}

Alkaline flocculation is a potentially useful method for microalgae bulk harvesting. The analysis from the response surface (RMS) methodology emphasized that $\mathrm{pH}, \mathrm{BC}$ and the interaction between the two factors all impact the alkaline flocculation process. The cell damage mechanism on high $\mathrm{pH}$ value conditions would be studied further. Like a rich and available resource of seawater, SOW addition to the freshwater algae culture can improve flocculating activity. The denser BC, the less SOW needed per unit of biomass amount.

\section{Acknowledgments}

This research was funded by the National Program on Key Basic Research Project of China (973 Program) (2011CB200905), the China Postdoctoral Science Foundation (2014M551519), the 12th Five Year Support Plan of the Ministry of Science and Technology, China (2011BAD14B03), the Senior Talent Scientific Research Initial Funding Project of Jiangsu University (14JDG024) and the Natural Science Foundation of Jiangsu Province (BK20140540).

\section{Author Contributions}

Shuhao Huo wrote the main part of the paper and performed the experiments. Zhongming Wang, Shunni Zhu, Renjie Dong, Zhenhong Yuan revised the paper. Other authors read and approved the manuscript.

\section{Conflicts of Interest}

The authors declare no conflict of interest.

\section{References}

1. Demirbas, A.; Demirbas, M.F. Algae Energy: Algae as a New Source of Biodiesel; Springer-Verlag: London, UK, 2010.

2. Huo, S.; Dong, R.; Wang, Z.; Pang, C.; Yuan, Z.; Zhu, S.; Chen, L. Available resources for algal biofuel development in China. Energies 2011, 4, 1321-1335.

3. Hu, Q.; Sommerfeld, M.; Jarvis, E.; Ghirardi, M.; Posewitz, M.; Seibert, M.; Darzins, A. Microalgal triacylglycerols as feedstocks for biofuel production: Perspectives and advances. Plant J. 2008, 54, 621-629.

4. Wang, B.; Li, Y.; Wu, N.; Lan, C.Q. $\mathrm{CO}_{2}$ bio-mitigation using microalgae. Appl. Microbiol. Biotechnol. 2008, 79, 707-718.

5. National Algal Biofuel Technology Roadmap; U.S. Department of Energy, Office of Energy Efficiency and Renewable Energy, Biomass Program: Washington, DC, USA, 2010.

6. Duan, J.; Gregory, J. Coagulation by hydrolysing metal salts. Adv. Colloid Interface Sci. 2003, 100-102, 475-502.

7. Ahmad, A.L.; Mat Yasin, N.H.; Derek, C.J.C.; Lim, J.K. Optimization of microalgae coagulation process using chitosan. Chem. Eng. J. 2011, 173, 879-882. 
8. Wu, Z.; Zhu, Y.; Huang, W.; Zhang, C.; Li, T.; Zhang, Y.; Li, A. Evaluation of flocculation induced by $\mathrm{pH}$ increase for harvesting microalgae and reuse of flocculated medium. Bioresour. Technol. 2012, 110, 496-502.

9. Yahi, H.; Elmaleh, S.; Coma, J. Algal flocculation-sedimentation by $\mathrm{pH}$ increase in a continuous reactor. Water Sci. Technol. 1994, 30, 259-267.

10. Schlesinger, A.; Eisenstadt, D.; Bar-Gil, A.; Carmely, H.; Einbinder, S.; Gressel, J. Inexpensive non-toxic flocculation of microalgae contradicts theories; overcoming a major hurdle to bulk algal production. Biotechnol. Adv. 2012, 30, 1023-1030.

11. García-Pérez, J.S.; Beuckels, A.; Vandamme, D.; Depraetere, O.; Foubert, I.; Parra, R.; Muylaert, K. Influence of magnesium concentration, biomass concentration and $\mathrm{pH}$ on flocculation of Chlorella vulgaris. Algal Res. 2014, 3, 24-29.

12. Vandamme, D.; Foubert, I.; Fraeye, I.; Meesschaert, B.; Muylaert, K. Flocculation of Chlorella vulgaris induced by high $\mathrm{pH}$ : Role of magnesium and calcium and practical implications. Bioresour. Technol. 2012, 105, 114-119.

13. Besson, A.; Guiraud, P. High-pH-induced flocculation-flotation of the hypersaline microalga Dunaliella salina. Bioresour. Technol. 2013, 147, 464-470.

14. Benjamin, T.S.; Robert, H.D. Sedimentation of algae flocculated using naturally-available, magnesium-based flocculants. Algal Res. 2012, 1, 32-39.

15. Brady, P.V.; Pohl, P.I.; Hewson, J.C. A coordination chemistry model of algal autoflocculation. Algal Res. 2014, 5, 226-230.

16. Rippka, R.; Deruelles, J.; Waterbury, J.; Herdman, M.; Stanier, R. Generic assignments, strain histories and properties of pure cultures of cyanobacteria. J. Gen. Microbiol. 1979, 111, 1-61.

17. Guillard, R.R.L. Culture of phytoplankton for feeding marine invertebrates. In Culture of Marine Invertebrate Animals; Smith, W.L., Chanley, M.H., Eds.; Plenum Press: New York, NY, USA, 1975; pp. 26-60.

18. Yang, Z.H.; Huang, J.; Zeng, G.M.; Ruan, M.; Zhou, C.S.; Li, L.; Rong, Z.G. Optimization of flocculation conditions for kaolin suspension using the composite flocculant of MBFGA1 and PAC by response surface methodology. Bioresour. Technol. 2009, 100, 4233-4239.

19. Blanchemain, A.; Grizeau, D.; Guary, J.C. Effect of different organic buffers on the growth of Skeletonema costatum cultures: Further evidence for an autoinhibitory effect. J. Plankton Res. 1994, 16, 1433-1440.

20. Lee, S.J.; Kim, S.B.; Kim, J.E.; Kwon, G.S.; Yoon, B.D.; Oh, H.M. Effects of harvesting method and growth stage on the flocculation of the green alga Botryococcus braunii. Lett. Appl. Microbiol. 1998, 27, 14-18.

(C) 2014 by the authors; licensee MDPI, Basel, Switzerland. This article is an open access article distributed under the terms and conditions of the Creative Commons Attribution license (http://creativecommons.org/licenses/by/3.0/). 